\title{
Characterization of Anti-HER2 scFv Gene Expression as Intracellular Protein in Escherichia coli BL21 (DE3)
}

\author{
Tina Rostinawati ${ }^{*}$, Nadia Gitta Paramita' ${ }^{1}$ Imam Adi Wicaksono², Sriwidodo ${ }^{3}$, Muhammad Yusuf $^{4}$, Toto Subroto ${ }^{4}$ \\ 'Department of Biology Pharmacy, Faculty of Pharmacy, Padjadjaran University, Sumedang, Jawa Barat, INDONESIA. \\ 2Department of Pharmacology and Clinical Pharmacy, Faculty of Pharmacy, Padjadjaran University, Sumedang, Jawa Barat, INDONESIA. \\ ${ }^{3}$ Department of Pharmaceutical and Pharmaceutical Technology, Faculty of Pharmacy, Padjadjaran University, Sumedang, Jawa Barat, INDONESIA. \\ ${ }^{4}$ Department of Chemistry, Faculty of Mathematics and Natural Sciences, Padjadjaran University, Sumedang, Jawa Barat, INDONESIA.
}

\begin{abstract}
Objectives: In patients with breast cancer, Human Epidermal Growth Factor is over expressed until $30 \%$. Monoclonal antibodies was an alternative detection cancer in molecular level. The aim of the experiment was protein recombinant of anti-HER2 scFv was constructed from the gene encoding single chain variable fragment of anti-HER2 antibody wich was fused with Histag and can be expressed in the Eschericia coli BL21(DE3) to be used as a diagnostic protein for breast cancer cells. Methods: The recombinant pJ401express_anti-HER2 scFv fused with histaq was transformed into $E$. coli BL21 (DE3) and expressed as recombinant anti-HER2 scFv protein with various inducer concentration. Then, those protein was purified with the nickel polyhistidine tag (Ni-NTA) affinity chromatography using imidazole concentration i.e 100 and $150 \mathrm{mM}$. Finally, the existence of this recombinant protein was determined with anti histaq antibody in western blot assay. Results: Plasmid isolation from E. coliBL21 (DE3) cells revelaed the existence of the recombinant pJ401express_anti-HER2 scFv. The optimum condition for using IPTG as inducer for the intracellular expressed
\end{abstract}

anti-HER2 scFv gene was $1 \mathrm{mM}$ IPTG which was entered into broth medium at the $3.5^{\text {th }}$ hr of growth time of E. coli BL21(DE3). Then, the higher amout of more purified anti-HER2 ScFv was obtained using imidazole at $150 \mathrm{mM}$. The recombinant protein was also bound to anti histaq antibody in western blot assay. Conclusion: the recombinant pJ401express_anti-HER2 scFv was successfully expressed as anti-HER2 scFv protein.

Key words: Recombinant protein, Fusion protein, Cell breakdown, Purification, Imidazole.

\section{Correspondence}

Dr. Tina Rostinawati

Department of Biology Pharmacy, Faculty of Pharmacy, Padjadjaran University, Kabupaten Sumedang, Jawa Barat-45363, INDONESIA.

Phone no: +62-81910252773

Email: tinarostinawati@gmail.com

DOI: 10.5530/ijpi.2020.2.21

\section{INTRODUCTION}

Breast cancer is one type of cancer that often occurs in women throughout the world. In Indonesia, breast cancer is the most dominant type of cancer, which is around $21.4 \%$ in 2014 when compared with patients with cervical, respiratory, ovarian and colon cancer. ${ }^{1}$ Diagnosis of breast cancer currently requires expensive instruments that are only available in big cities in Indonesia.

In breast cancer, human epidermal growth factor (HER) 2 is an overexpressed (about 30\% overexpression) transmembrane receptor tyrosine kinase. Several treatments and diagnoses for breast cancer targeting HER2 have been carried out by various studies, one of which is the development of monoclonal antibodies (mAbs). One mechanism of tumor cell polyperation can be inhibited by inhibiting HER 2 by targeting the extracellular domain with specific antibodies. The development of monoclonal antibodies with this HER2 target has significantly increased the survival of patients by up to $20 \%$ of patients with breast cancer. ${ }^{2-4}$

The use of monoclonal antibodies (mAbs) is more often used to diagnose cancer at the molecular level compared to polyclonal antibodies. This is because mAbs has a higher level of accuracy, sensitivity, specificity and reproducibility compared to polyclonal antibodies. ${ }^{5}$ In this study a recombinant protein was designed using a single chain fragment variable (scFv) from the antiHER2 antibody.

Variariable single chain fragment antibodies ( $\mathrm{scFv}$ ) consist of variable sites where there are heavy chain variable and light chain variable linked by petides which are often referred to as linkers. This single chain fragment variable can be expressed functionally using E. coli bacteria. ${ }^{6}$
These linkers or connecting peptides must have a hydrophilic amino acid sequence. This is done to avoid peptide squeezing or intercalation between all domains of variable protein folding. The amino acid sequence consisting of glycine and serine which plays a role in flexibility and can be used only with interspersed residues to increase its solubility such as the addition of glutamic acid and lysine is currently one of the most widely used designs. ${ }^{7}$

The advantages of using scFv to detect antigens that scFv can be produced on a large scale using a bacterial expression system so the cost is lower. Scfv still has a special affinity for antigens but is usually not greater when compared to the original antibody. This $\mathrm{scFv}$ protein can be combined with radioisotopes or poisons to effectivelly enhance cancer therapy in cancer patients. $^{8}$

In this research recombinant protein is designed to be expressed as an intracellular protein to make it easier to obtain the protein compared to extracellular protein. ${ }^{9}$ This recombinant protein will be used as a dipstick kit. ${ }^{10}$ This diagnostic is easy to use so that it can be widely used in remote areas in Indonesia where there are no adequate health facilities for breast cancer diagnosis. So that breast cancer can be detected earlier so that patients can be cured and breast cancer death cases can be reduced.

\section{MATERIAL AND METHODS}

\section{pJ401express-anti-HER2 scFv vector construction}

Sequence of anti-Her2 scFv human protein was derived from NCBI Database protein (https://www.ncbi.nlm.nih.gov/protein) with code 
4LLU and used scFv fragment. Variable ligt and variable heavy of scFv were joined using cysteine modified linker. This $\mathrm{scFv}$ was translated to nucleic acid using tools https://www.ebi.ac.uk/Tools/st/emboss_ backtranse.q/. In addition, scFv gene was added with DNA sequence encoding ribosome binding site, spacer, NdeI, histag, stop codon and EcoRI. This DNA sequence was ligated with pJ401express vector and expressed $\mathrm{scFv}$ protein was designed as intracellular protein and diferrent with previous produced $\mathrm{scFv} .{ }^{9}$

\section{Transformation of pJ401express_anti-HER2 scFv vector to Eschericia coli BL21(DE3)}

pJ401express-anti-HER2 ScFv synthetic gene produced by ATUM was transformed to E. coli BL21(DE3) with heat shock method. The competent $E$. coli BL21(DE3) cell was first prepared. The competent cell was taken as much as $50 \mu \mathrm{l}$ and inserted into the microtube. A number of $1 \mu \mathrm{l}$ of $\mathrm{pJ} 401$-anti-HER $2 \mathrm{scFv}(1 \mathrm{ng} / \mu \mathrm{L})$ was added to $50 \mu \mathrm{l}$ competent cells then mixed by gently tapping of microtube and put it in an iced box for $30 \mathrm{~min}$. After that, the microtube laid out in a $42^{\circ} \mathrm{C}$ water bath for $90 \mathrm{sec}$ and immediately placed in an iced box for $2 \mathrm{~min}$. Then, LB broth medium was added into the microtube as much as $250 \mu$ without antibiotic. The microtube was incubated in shaker incubator with a speed of $200 \mathrm{rpm}$ at $37^{\circ} \mathrm{C}$ for $1 \mathrm{hr}$. A number of $100 \mu \mathrm{l}$ of a mixture of plasmids and competent cells was spread on LB agar containing $25 \mu \mathrm{g} / \mathrm{ml}$ of kanamycin and incubated at $37^{\circ} \mathrm{C}$ for $24 \mathrm{hr} .^{11,12}$

\section{Recombinant vector isolation}

The transformant colonies of E. coli BL21(DE3) was inoculated into 5 $\mathrm{mL} \mathrm{LB}$ broth medium with $25 \mu \mathrm{g} / \mathrm{mL}$ of kanamycin and incubated for at $37^{\circ} \mathrm{C}$ with shaking speed of $200 \mathrm{rpm}$ for $18 \mathrm{hr}$ for making bacterial culture. The pellet cell was prepared by centrifugation the bacterial culture at 8,000 rpm for $2 \mathrm{~min}$. Recombinant vector was further obtained from these pellet cells. Isolation of recombinant vector was carried out using Gene Jet Miniprep Kit. The isolation procedure followed the kit protocol. The isolated recombinant vector was further migrated in electrophoresis gel using TAE $1 \mathrm{x}$ buffer with $80 \mathrm{~V}$ for $45 \mathrm{~min}^{9}$

\section{The growth curve of recombinant Eschericia coli BL21(DE3)}

The recombinant E. coli BL21(DE3) was inoculated into $5 \mathrm{ml} \mathrm{LB}$ broth medium with kanamycin $(25 \mu \mathrm{g} / \mathrm{ml})$ and incubated in incubation shaker at $200 \mathrm{rpm}, 37^{\circ} \mathrm{C}$ for $18 \mathrm{hr} .1 \mathrm{ml}$ of this culture was added into an erlenmeyer flask containing $100 \mathrm{~mL}$ of LB broth with kanamycin (25 $\mu \mathrm{g} / \mathrm{ml}$ ) incubated in shaker incubation at $200 \mathrm{rpm}$ and $37^{\circ} \mathrm{C}$. The optical density of culture was monitored at $1,2,3,4,5,6,24$ and $25 \mathrm{~h}$ after incubation. The OD value was measured using Spectrophotometer at $\lambda$ $=600 \mathrm{~nm}^{9}$

\section{Anti-HER2 scfv gene expression in Eschericia coli BL21(DE3)}

The recombinant $E$. coli BL21(DE3) culture was prepared the same as procedure to determine growth curve of bacterial cell. IPTG as inducer was added at induction point i.e at time the $\mathrm{OD}_{600 \mathrm{~nm}}=0.7$ was reached. Then, the bacterial culture was incubated until it reached the initial point of the stationary phase of the bacterial growth curve. To find out the IPTG optimum concentration as inducer to highest yield of recombinant protein, the various IPTG concentration was used i.e. 0.1, 0.5, 1, 1.5 and $2 \mathrm{mM}^{9}$

\section{Isolation of recombinant protein}

The pellet cell was harvested by centrifugation $100 \mathrm{ml}$ of LB broth at $200 \mathrm{rpm}, 4^{\circ} \mathrm{C}$. The pellet cells were resuspensed by adding $500 \mu \mathrm{L}$ of sonication buffer and lysed using a sonicator. The lysis process was carried out in a cold state for 3 cycles. Each cycle went on $2 \mathrm{~min}$, with sonicator condition was turn on for $2 \mathrm{sec}$ and turn off for $2 \mathrm{sec}$ resfectively. The sonicator was off for $4 \mathrm{~min}$ between cycles. Then, the crude extract protein was separated from debris cells by centrifugation process at $10,000 \mathrm{~g}$ at $4^{\circ} \mathrm{C}$ for $30 \mathrm{~min}$. The supernatant part was placed into mirotube as a dissolved fraction. ${ }^{11}$ The recombinant protein was visualized with $12 \%$ SDS Page gel.

\section{Purification of recombinant protein}

The recombinant protein was carried out using the Qiagen QIA express NI-NTA Fast Start kit. The procedure is carried out according to the protocol available in the kit. The crude recombinant protein was inserted into the column. The crude solution was allowed to interact with the column for $15 \mathrm{~min}$. After that, the column cover was opened and flowtrough fraction was obtained. The column was further washed using $4 \mathrm{ml}$ wash buffer twice and washing fractions were collected. Finally, the column was eluted by using $1 \mathrm{ml}$ of elution buffer twice and this fraction was stored. All the fraction shouid be stored in $20^{\circ} \mathrm{C}$. All fractions were then analyzed using $12 \%$ SDS-PAGE gel. ${ }^{13}$ To obtain the higher purity of recombinant protein, the purification process was performed using with gradual imidazole i.e 100 and $150 \mathrm{mM}$.

\section{Determination recombinant protein as anti-Her2 scFv protein}

The pure recombinant protein was migrated in the $12 \%$ SDS PAGE gel. Then, the protein was transferred to the nitrocellulose membrane. This membrane was laid out on petri dish and the protein was stained using a ponceau for $30 \mathrm{~min}$ and continued with destaining process using aquadest for $30 \mathrm{~min}$. The membrane was further rinsed using PBST as washing solution for $2 \times 5 \mathrm{~min}$. The membrane side that undergoes the protein transfer process from the gel was directed to the surface. The skim milk dissolved in PBST as blocking buffer was poured over the membrane surface and blocking process took $1 \mathrm{hr}$ at room temperature. Then, the blocking buffer was removed from the Petri dish and membrane was poured with $0.5 \mu \mathrm{g} / \mathrm{ml}$ of anti-Histag protein solution. The membrane was then shaken overnight at $4^{\circ} \mathrm{C}$. This solution was removed and the membrane was rinsed with washing buffer (PBST solution) and shaken for $4-5 \times 5 \mathrm{~min}$. Furthermore, $1 \mu \mathrm{g} / \mathrm{ml}$ of anti-mouse IgG HRP-conjugated antibody (R\&D System, USA) solution was poured to the membrane shaken for $2 \mathrm{hr}$ at room temperature. Then, this solution was removed and the membrane was rinsed with washing buffer (PBST solution) and was shaken $4-5$ x 5 min. Finally, the membrane was placed on the Petri dish added chemiluminescent solution and was incubated for 3-5 min at room temperature. The imaging process was carried out on a C-DiGit blot scanner. ${ }^{14}$

\section{RESULTS}

The Gene encoding anti-HER2 scFv was constructed as recombinant vector i.e. pJ401express_antiHER2_scFv (Figure 1). Anti-HER2 scFv gene was designed using scFv-cys linker fused with nucleotide encoding histaq. This gene was expressed as intracellular recombinant protein.

The recombinant vector had been further transformed in E. coli BL21(DE3). As result of plasmid isolation run in DNA electrophoresis gel using ethidium bromide revealing there were two bands of DNA with its size was 4686 bp (Figure 2). So, this recombinant vector was succesfully transformed in E. coli BL21(DE3).

Furthermore, the growth curve of E. coli BL21(DE3) was displayed in Figure 3. This curve revealed that Optical Density $\left(\mathrm{OD}_{0.7 \mathrm{at} 600 \mathrm{~nm}}\right)$ was reached at $3.5^{\text {th }} \mathrm{hr}$. 
Furthermore, IPTG as induser was added in broth culture at $3.5 \mathrm{hr}$ after incubation. The result of the expression of anti-HER2 scFv gene using various IPTG concentration was displayed on the SDS Page gel revealed bands with measurements based on theoretical calculations of $27 \mathrm{kDa}$ (Figure 4). So based on this data, the optimum concentration of used IPTG was $0.5 \mathrm{mM}$. In addition to recombinant proteins there were also other proteins which were displayed on the $12 \%$ SDS Page gel.

Then the recombinant protein was purified using Ni-NTA affinity Chromatography. This result was displayed in 12\% SDS PAGE (Figure 5). Recombinant protein was bound at Ni-NTA coloumn chromatography. Even though, not all recombinant proteins was bound at coloumn, in part of those were still in flow through and washing fractions. So, the amount of the recombinant protein in the elution fraction was not much. Even in the elution fraction there were still some non-target proteins.

The recombinant protein further purified with gradual elution using a lower concentration of imidazole was performed in Figure 6. The recombinant protein was successfully purified as a single protein in the use of both concentrations of imidazole.

Finally, the recombinant protein must be confirmed as an anti-HER2 $\mathrm{scFv}$ protein. The result of Western blot test of recombinant protein was revealed in the Figure 7 . The protein recombinant was noticeable bound with anti Histaq antibody as primer antibody. The recombinant protein was fused with Histaq. So, the recombinant protein which was expressed from anti-HER2 scFv gene was anti-HER2 scFv protein.

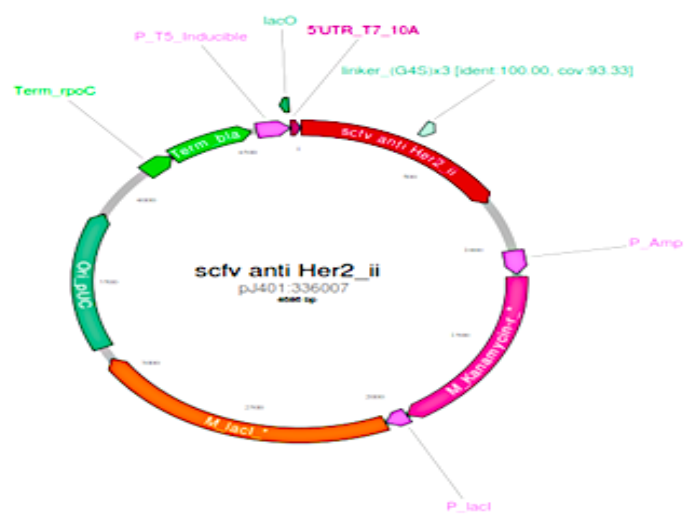

Figure 1: Map of Construction of pJ401 express_anti-HER2 scFv shynthetic gene.

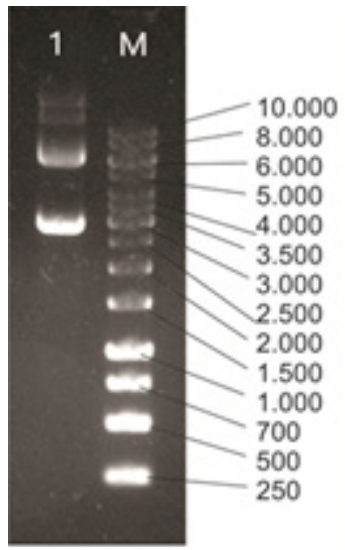

Figure 2: Plasmid isolation result of recombinant vector from transformed E. coli BL21(DE3) with pJ401express_anti-HER2 scFv. Lane 1: band of plasmid isolation, Lane M: DNA marker.

\section{DISCUSSION}

The anti-HER2 scFv was desained using scFv-cys linker. The desained $\mathrm{scFv}$ with this linker performed the stable bond with the nano gold particle. ${ }^{15}$ This target protein will be conjugated with gold nanoparticle to be used as a diagnostic kit. A strong binding affinity between AuNP and anti-HER2 scFv is needed so AuNP can be conjugated against antiHER2 scFv. The design and synthesis of the proper scFv conjugation is a key step in this method. It is emphasized that the location of cysteines in $\mathrm{scFv}$ is important for maintaining the affinity of scFv binding. Reports indicate that cysteine residues at the end of the C-terminal affinity tag are far more reactive to gold clusters than cysteine residues in the $\mathrm{scFv}$ frame work region. ${ }^{15}$ AuNP through the formation of self-assembled monolayers with thiol groups in which the $S$ atom in the thiol group will provide its free electron pair to the gold $(\mathrm{Au})$ atom so that the covalent bonds of the Au-S coordination occur. The presence of chemical bonds (covalent coordination bonds) between Au-S will make AuNP more stable. $^{16}$

This recombinant protein was also designed using pJexpress vector. Gene expression using this vector had previously been able to produce sufficient recombinant proteins. ${ }^{17}$ This vector use lac operon system which can produce high amounts of recombinant protein. ${ }^{18}$ The recombinant protein to be expressed too as intracellular protein to supplement this anti-HER2 scFv which had previously been designed as an extracellular protein. ${ }^{9}$ Some literature shows the advantages of extracellular protein

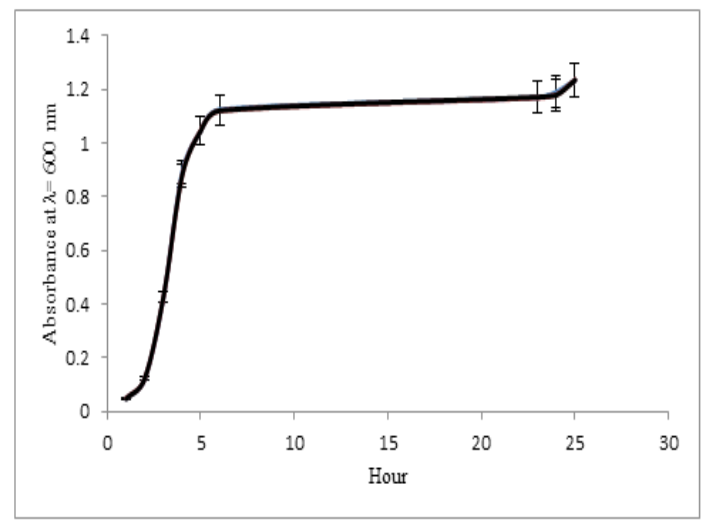

Figure 3: Growth curve of recombinant E. coli BL21(DE3).

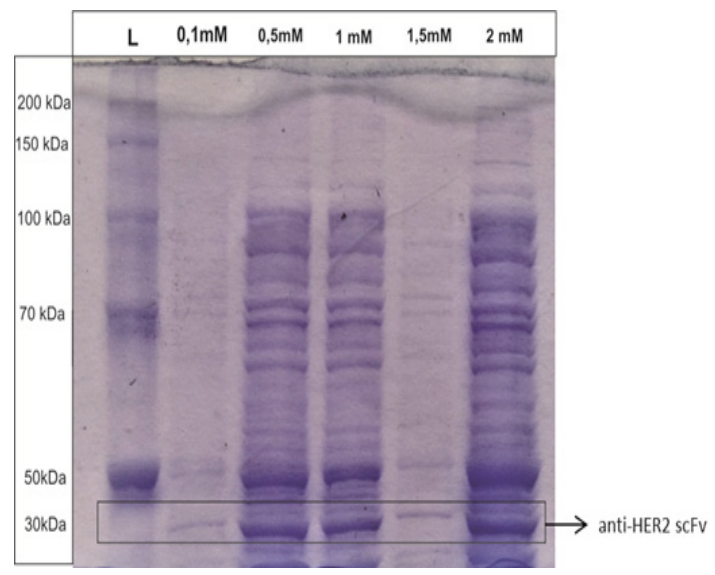

Figure 4: Result of anti-HER2scFv gene expression using various IPTG concentration as inducer. 


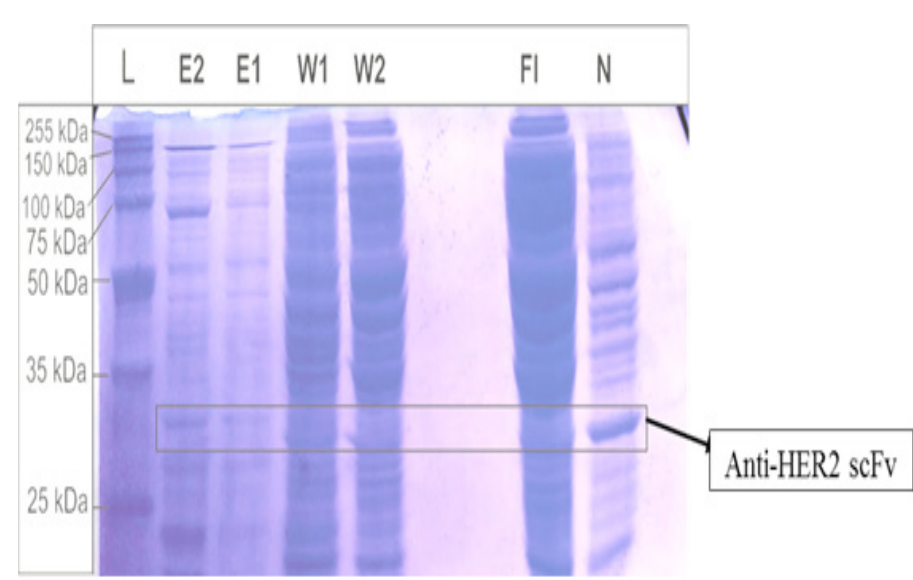

Figure 5: Purification of recombinant protein using Ni-NTA affinity chromatography $\mathrm{L}=$ ladder, $\mathrm{N}=$ crude protein, $\mathrm{W} 1=$ washing fraction $1, \mathrm{~W} 2=$ =washing fraction 2, E1= Elution Fraction 1, E2=Elution fraction 2.

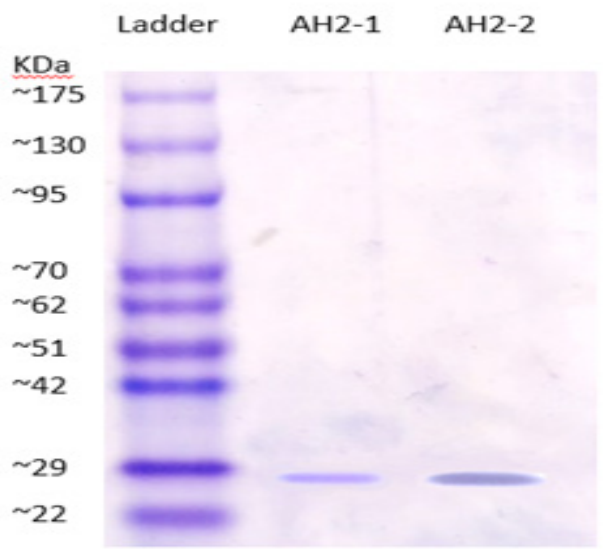

Figure 6: Result of recombinant protein using Ni-NTA affinity chromatography with 100 and $150 \mathrm{mM}$ of imidazole. AH2-1: $100 \mathrm{mM}$ of imidazole, AH2-2: $150 \mathrm{mM}$ of imidazole.

however the released protein was likely unstable by the condition of fermentation process i.e. high aeration shear environment. ${ }^{19}$ The strain host used in recombinant protein production was chosen $E$. coli BL21(DE3). This strain can produce the highest target protein. ${ }^{20}$ E. coli BL21(DE3) has lambda (DE3) prophage in its genome that encoding T7 RNA Polymerase under control a lac UV5 promotor, is induced by IPTG. $^{21}$

Furthermore, the synthetic recombinant vector must be in the E. coli BL21(DE3). Its existence was revealed as two bands in agarose gel. Intercalated DNA with EtBr leads structure of DNA to linear and closed circular molecule. ${ }^{11}$ The main reason for using BL21(DE3) as a host is this strain lacks in the Lon and OmpT proteases which can degrade protein so that this strain can reduce degradation of recombinant proteins. In addition, E. coli BL21 produces a low amount of acetate compared to other strains. Acetate can inhibit the growth and formation of recombinant proteins, even at low concentrations of $0.5-1 \mathrm{~g} / \mathrm{L}$. Low acetate production by BL21 will generally produce higher recombinant protein yields. ${ }^{22}$

The optimum conditions for the amount of used IPTG as inducer in this study was OD $0.7(600 \mathrm{~nm})$ achieved in $3.5 \mathrm{~h}$. This OD was the induction point to add IPTG as inducer into broth medium. Whereas, OD 0.7 at $600 \mathrm{~nm}$ was reached at $4 \mathrm{~h}$ and OD 0.9 at $600 \mathrm{~nm}$ was at $3 \mathrm{rd} \mathrm{h.} .^{9,12} \mathrm{OD}$ is commonly used by researchers as a moment of the pattern of bacterial

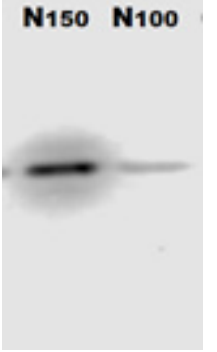

Figure 7: Determination of recombinant protein as anti-HER2 scFv protein using western blot method. N100: anti HER2 ScFv recombinant purified using $100 \mathrm{mM}$ of imidazole, N150: anti HER2 ScFv recombinant purified using 150 $\mathrm{mM}$ of imidazole.

growth to move from the cell growth phase to the phase of protein production by adding the IPTG inducer. ${ }^{21,23,24}$

Purification result with Ni-NTA affinity chromatography showed the presence of non-target proteins that were eluted from the column. This is due to some cellular proteins contain two or more adjacent histidine residues. So those residues can bind to the metal contained in the matrix. ${ }^{25,26}$ The use of a gradual imidazole concentration elution solution can remove impurity proteins. ${ }^{17}$

Ultimately, this recombinant protein was detected as an histaq protein using anti-histag antibody. The Histaq protein can tightly bind to antihistaq antibody. ${ }^{27}$ The anti-HER2 $\mathrm{scFv}$ is fused protein with histaq residue.

\section{CONCLUSION}

The anti-HER2 scFv synthetic gene can be expreseed in E. coli BL21(DE3) as intracellular anti_HER2 scFv protein. This pure protein was obtained by using a lower concentration of imidazole.

\section{ACKNOWLEDGEMENT}

The authors thank The Biotechnology Study Centre of Padjadjaran University for providing the E. coli BL21(DE3) and Padjadajran University which has provided research grant.

\section{CONFLICT OF INTEREST}

The authors declare no conflict of interest.

\section{ABBREVIATIONS}

HER2: Human epidermal growth factor receptor 2; scFv: Single-chain fragment variable.

\section{REFERENCES}

1. World Health Organization. Cancer Country Profiles: Indonesia. Cancer Country Profiles 2014. https://www.who.int/cancer/country-profiles/en/

2. Gu G, Dustin D, Fuqua, SA. Targeted therapy for breast cancer and molecular mechanisms of resistance to treatment. Curr Opin Pharmacol. 2016;31:97-103.

3. Luque-Cabal M, García-Teijido P, Fernández-Pérez $Y$, Sánchez-Lorenzo L, Palacio-Vázquez I. Mechanisms behind the resistance to trastuzumab in HER2amplified breast cancer and strategies to overcome clinical medicine insights Oncology. 2016;10(Suppl 1):21-30.

4. Sommaruga S, Lombardi A, Salvadè A, Mazzucchelli S, Corsi F, Galeffi P, et al. Highly efficient production of anti-HER2 scFv antibody variant for targeting breast cancer cells. Appl Microbiol Biotechnol. 2011;91(3):613-21.

5. Zhang X, Soori G, Dobleman TJ, Xiao GG. The application of monoclonal antibodies in cancer diagnosis. Expert Rev Mol Diagn. 2014;14(1):97-106.

6. Griffiths AD, Duncan AR. Strategies for selection of antibodies by phage display. Curr Opin Biotech. 1998;9(1):102-8.

7. Ahmad ZA, Yeap SK, Ali AM, Ho WY, Alitheen NBM, Hamid M. ScFv antibody: 
Principles and clinical application. Clin Dev Immunol. 2012;15. Article ID 980250.

8. Aracama M. Development of a tagged scFv based immunoprecipitation method for protein-protein interaction studies: Thesis. West Virginia University, West Virginia (USA). 2007.

9. Rostinawati T, Kusuma SAF, Yusuf M, Gaffar S, Subroto T. Construction and Expression of Synthetic-gene anti_HER2 scFv Fused with PelB in Escherichia coli BL21 (DE3). J Pharm Sci Res. 2017;9(11):2106-13.

10. Gandhi S, Banga I, Maurya PK, Eremin SA. A gold nanoparticle-single-chain fragment variable antibody as an immunoprobe for rapid detection of morphine by dipstick. RSC Advance. 2018;8(3):1511-8.

11. Green MR, Sambrook J. Molecular Cloning: A Laboratory Manual. $4^{\text {th }}$ Edition. New York: Cold Spring Harbor. 2012

12. Kusuma SAF, Parwati I, Rostinawati T, Yusuf M, Fadhlillah M, Tanti LD, et al. Construction and Expression of Synthetic Gene Encoding MPT64 as Extracellular Protein in Escherichia coli BL21 (DE3) Expression System. J Pharm Sci Res. 2018;10(10):2659-65.

13. Qiagen. QIA express ${ }^{\circledR}$ Ni-NTA Fast Start Handbook For purification and detection of recombinant 6xHis-tagged protein. OIAGEN Sample and Assay Technologies. 2011;7-24.

14. Liem S, Rostinawati $T$, Lesmana R, Sumiwi SA, Milanda T, Mutakin M, et al. Modulation of caspase-3 expression by Arcangelisia flava post acetaminopheninduced hepatotoxicity in rat's liver. InaBJ. 2018;10(2):148-55.

15. Liu Y, Liu Y, Mernaugh RL, Zeng $X$. Single chain fragment variable recombinant antibody functionalized gold nanoparticles for a highly sensitive colorimetric immunoassay. Biosens Bioelectron. 2009;24(9):2853-7.

16. Alison MW, Reed JM, Steven JM. Oriented Protein Adsorption to Gold Nanoparticles through a Genetically Encodable Binding Motif. Langmuir. 2010;26(24):18945-50

17. Rostinawati T, Riani C, Elfahmi YC, Retnoningrum DS. Y93F Substitution
Cyclodextrin Glucanotransferase from Bacillus sp. A2-5a and Its Enzyme Characterization. Biotechnology. 2015;14(4):181-7.

18. Davanloo P, Rosenberg AH, Dunn JJ, Studier FW. Cloning and expression of the gene for bacteriophage T7 RNA polymerase. Proc Natl Acad Sci USA. 1984;81(7):2035-9.

19. Middelberg AP. Process-scale disruption of microorganisms. Biotechnol Adv. 1995;13(3):491-551.

20. Marisch K, Bayer K, Cserjan-Puschmann M. Evaluation of three industrial Escherichia coli strains in fed-batch cultivations during high-level SOD protein production. Microb Cell Fact. 2013;12(1):58.

21. Jeong H, Kim HJ, Lee SJ. Complete Genome Sequence of Escherichia coli strain BL21. Genome Announc. 2015;3(2):e00134-15.

22. Waegeman H, Lausnay, SD, Beauprez J, Maertens J, De MM, Soetaert W. Increasing recombinant protein production in Escherichia coli K12 through metabolic engineering. N Biotechnol. 2013;30(2):255-61. DOI: 10.1016/j. nbt.2011.11.008

23. Axambayeva AS, Shustov AV. Recombinant thermotolerant phytase produced in E. coli. Proceedings of CBU International Conference, Prague, Czech Republic. Prague: Central Bohemia University. 2015;3:3-5.

24. Nekrasova O, Tagway A, Ignatova A, Feofanov A, Kirpichnikov M. Studying of Membrane Localization of Recombinant Potassium Channels in E.coli. Acta Naturae. 2009;1(1):91-5.

25. Kumar $M$, Singh $M$, Singh SB. Optimization of conditions for expression of recombinant interferon- $\gamma$ in E.coli. Mol Biol Rep. 2014;41(10):6537-43.

26. Schmitt J, Hess $H$, Stunnenberg HG. Affinity purification of histidine-tagged proteins. Mol Biol Rep. 1993;18(3):223-30.

27. Kaufmann M, Lindner $\mathrm{P}$, Honegger A, Blank K, Tschopp M, Capitani G, et al Crystal Structure of the Anti-His Tag Antibody 3D5 Single-chain Fragment Complexed to its Antigen. J Mol Biol. 2002;318(1):135-47.

Article History: Submission Date : 22-12-2019; Revised Date : 27-01-2020; Acceptance Date : 18-02-2020.

Cite this article: RostinawatiT, Paramita NG, Wicaksono IA, Sriwidodo, Yusuf M, Subroto T. Characterization of Anti-HER2 scFv Gene Expression as Intracellular Protein in Escherichia coli BL21 (DE3). Int. J. Pharm. Investigation. 2020;10(1):117-21. 